\title{
UNIVERSAL CRIMINAL JURISDICTION: NEW APPROACH IN WESTERN EUROPEAN COUNTRIES
}

\section{SAFWAN MAQSOOD}

safwan.maqsood@gmail.com

Assistant Professor of Public International Law, University of Sharjah- College of Law (United Arab Emirates). He is Ph.D in International Law. He has taught at other Universities in Dubai and Mosul. He is author of numerous scientific articles in Arabic, French and English language.

\section{Abstract}

This paper focuses on universal criminal jurisdiction in western European countries. Although the International Criminal Court has facilitated some compliance with the Statute of Rome 1998, some European countries have been criticised for placing restrictive conditions on the exercise of this jurisdiction. However, with the Syrian Conflict and the emergence of terrorist groups, universal jurisdiction has again been proposed to prosecute war crimes and crimes against humanity by perpetrators who have sought asylum in Europe.

\section{Keywords}

International criminal law, torture, universal criminal jurisdiction, extradition

\section{How to cite this article}

Maqsood, Safwan (2021). Universal Criminal Jurisdiction: New Approach in Western European Countries. Janus.net, e-journal of international relations. Vol12, №. 1, May-October 2021. Consulted [online] at date of last visit, https://doi.org/10.26619/1647-7251.12.1.11

Article received on October 8, 2020 and accepted for publication on March 17, 2021

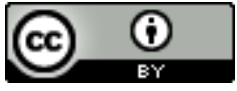




\title{
UNIVERSAL CRIMINAL JURISDICTION: NEW APPROACH IN WESTERN EUROPEAN COUNTRIES
}

\author{
SAFWAN MAQSOOD
}

\section{Introduction}

The prosecution of the perpetrators of international crimes is a rule of international criminal law, since otherwise, the perpetrator escapes punishment and the criminal justice system fails. This prosecution may be through permanent or adhoc international criminal courts, or by ordinary criminal jurisdiction exercised by national courts. Very often, however, we are faced with the impossibility of applying either of these criminal jurisdictions, and for the sake of bringing justice to the victims of international crimes and preventing impunity for their perpetrators, it is necessary to accept universal criminal jurisdiction. Today, we face crimes of a special nature which threaten the international peace and security of humanity ${ }^{1}$.

For this reason, universal criminal jurisdiction (UCJ) has recently been adopted as a practical and realistic solution to the dangerous and extensive spread of international crimes. The first exercise of this jurisdiction appeared with legal texts enacted seventy years ago, in the four Geneva Conventions of 1949 and their first additional protocol ${ }^{2}$. Later, the importance of this jurisdiction can be seen in UN Commissions. In this regard, we refer to the International Law Commission (ILC) and the Sixth Commission of General Assembly of the United Nations (GAUN), which adopted the Universal Jurisdiction as one of their works in $2010^{3}$. Different countries worldwide, especially in Europe, with punitive laws employ this jurisdiction to prosecute the perpetrators of very serious crimes. Such laws do so regardless of the nationality of the accused or victim, and wherever these crimes are committed, as they affect the whole international community ${ }^{4}$. In other words, States are obliged to respect the international commitment to extradite or prosecute ${ }^{5}$. As various countries have amended their national laws to incorporate universal

1 Klip, André (2008). «Universal Juridiction: Report for Europe», 79 Revue International de Droit Pénal, 180; Langer, Máximo (2015). «Universal Jurisdiction is Not Disappearing», 13:2 Journal of International Criminal Justice 249.

2 Kontorovich, Eugene (2008). «The Inefficiency of Universal Jurisdiction», 1 University of Illinois Law Review 408.

3 See: GAUN-6th Commission, 73 Session, GA/3571, 10-10-2018. See more: GAUN, Res. 64/117 (January/15/20210).

4 Shaghaji Danial Rezai (2015). «L'exercice de la compétence universelle en tant qu'obligation Erga Omnes afin de réprimer les crimes de Jus Cognes», Revue International de Droit Comparé 8.

5 Jalloh Charles (2018). Universal Criminal Jurisdiction, ILC, Doc. A/73/10, p. 310. 
jurisdiction into their legal systems, they are thus facilitating its employment by their national courts in the repression of international crimes ${ }^{6}$.

Such repression is required, despite the difficulties related to national laws of amnesties from punishment, and the immunity enjoyed by political and military leaders in various countries ${ }^{7}$. The absence of an international consensus -especially from major countries such as the United States, Russia and China - on the legitimacy and importance of the International Criminal Court (ICC) as a mainly international judicial organ for the prosecution of the perpetrators of international crimes means that the UCJ has become a principal factor in the international campaign against the suppression of international crimes $^{8}$. Many States members in the Sixth Commission of GAUN, in its $73^{\text {rd }}$ meeting issued statements refusing to adopt the UCJ in their national laws due to the lack of scope and definition of the $\mathrm{UCJ}^{9}$. Other groups of Statas like the the African group, the Caribbean Group, the Latin American Group and the Non-aligned Group found that this jurisdiction targeted only the less powerful states ${ }^{10}$.

However, the 'great powers', in addition to their negative stance towards the ICC, have adopted an even stricter stance against UCJ, seeing its practice as a serious threat by one country to the sovereignty of another. Moreover, territorial integration, especially when exercising $\mathrm{UCJ}$, is conditional on the failure to exercise the UCJ in absentia ${ }^{11}$. Despite the negativity of the great powers, European practice is generally based on legal and judicial transparency in accepting or rejecting the jurisdiction, contrary to what is prevalent in countries elsewhere. Such countries still lag behind either in incorporating UC] within their national law, or in its exercise before their national courts if stipulated in national law. The European positivity towards UCJ justifies our selection of specific countries with experience of this form of jurisdiction. For example, we examine whether a certain country considers its commitment to exercising UCJ to be based on a treaty to which it is a party, or if its practice of UCJ is in accordance with a national law rather than stemming from an international obligation ${ }^{12}$. A further question that arises is whether Europe today is trying to re-define the principle of UCJ after it has lost real meaning for many countries in the past decade, or if we are facing a new kind of UCJ with different specifications from those previously known.

6 Pradelle, Geraud (2000). La compétence universelle, (dir) Ascensio, Hervé droit international pénal, Paris : Editions A-Pédone, p.906.

7 Kontorovich, Eugene, supra note 2 at 413.

8 Heller, Kevin Joe (2017). «What Is an International Crime? A Revisionist History», $58: 2$ Harvard International Law Journal 401.

9 See: GAUN-6th Commission, 73 Session, GA/3571, 10-10-2018.

10 Jalloh Charles, supra note at 5, p. 309.

11 Garrod, Matthew (2018). «Unraveling the Confused Relationship between Treaty Obligations to Extradite or Prosecute and universal Jurisdiction in the Light of the Habre Case, 59:1, Harvard International Law Journal 150.

12 Pradelle, Geraud, supra note 3 at 906 . It should be noted here that the EU have a progressive position by encouraged its members States for adopt the Universal Jurisdiction in their national laws, for this aim the EU organized several Workshops and published many projects of UJ Codes. For more read: Garrod, Matthew (2019). «The Emergence of Universal jurisdiction in Response to Somali Piracy: An Empirically Informed Critique of International Law's Paradigmatic Universal Jurisdiction», 18 Chines Journal of International Law 560 . 


\section{Universal jurisdiction: a great disappointment}

The inclusion of universal jurisdiction in the national laws of European countries in the 1990 s had a positive effect in reviving hope among the victims of international crimes that they might see the perpetrators of these crimes tried and punished ${ }^{13}$. In the past thirty years, European countries in particular have witnessed major positive and negative changes linked to political tensions in countries where there have been war crimes, genocide, or crimes against humanity. Belgium was the first to enact a national law on UCJ in 1993, and amended it in 1999. Subsequently, Belgian courts issued several arrest warrants for the heads of foreign States, governments, foreign affairs ministers, and military leaders, based on the commission of serious crimes, either in their own countries or elsewhere, against victims of the same nationality or another. These arrest warrants were issued in European countries such as Spain, France, and Germany ${ }^{14}$. However, due to the political and economic pressure exerted by the great powers, especially the United States, many European countries which had adopted UCJ within their national laws modified these laws to make the practice of this jurisdiction very restricted, if not almost abolished. Just as Belgium was the first to enact UCJ, it was also the first European country to amend its national laws with procedures to restrict its practice, that is, it restricted the movement of the complaint to the Federal Public Prosecutor, which is a new job created for this purpose. And it specified the presence of the victim in Belgium, and to be legally resident therein, in addition to the presence of the accused on Belgian territory. Belgium thus abolished the element of UCJ in absentia, upon which most complaints had already relied ${ }^{15}$.

Belgium's actions were followed by Spain in 2009, when the latter severely restricted the practice of UCJ. Four years after the Spanish Constitutional Court endorsed UCJ in 2005 as a legal principle through which to achieve criminal justice for victims, whatever their nationality and whoever had committed a crime against them, the Spanish Parliament, under pressure from the USA and China, restricted the application of UCJ by modifying Article 23(4) of Ley organica del poder judicial. This modification makes it difficult, if not impossible, to apply UCJ ${ }^{16}$.

\subsection{Victims and their torturers on the streets of Amsterdam}

Although the Amsterdam Court of Appeal recognized the partial application of UCJ, particularly in the case of Desire in 2000 , it subsequently rejected several complaints based on $\mathrm{UCJ}$, perhaps because of the situation it had seen unfolding in its neighbouring

13 Cassese, Antonio (2002). Crimes internationaux et juridictions internationales. Paris: PUF, p. 19.

14 Vandermeersch, Damien (2003). «La fiabilité de la règle de la compétence universelle», (dir) Fronza, Emanuela et Manacorda, Stefano, La justice pénale internationale dans les décisions des tribunaux ad hocEtudes Law Clinics en droit pénal international, Milano, Giuffré Editoire, p .221. Also read: Langer, Máximo, supra note 1 at 254.

15 Kalek, Wolfgang (2009). «From Pinochet to Rumsfeld: Universal Jurisdiction in Europe 1998-2008», 30:3 Michigan Journal of International Law 934.

16 Massé, Michel (2008). «Chronique de droit pénal international», 3 Revue de Science Criminelle et de Droit Pénal Comparé, 447. Read also: The application of Universal Jurisdiction in the fight against impunityReport published by European Union in 2016, p. 18. 
country, Belgium ${ }^{17}$. Here, we refer to the Nazbali case of the Democratic Republic of the Congo and the case of the three Afghans, also known as the Gallozi case, all of whom accused of committing torture in their countries and who fled to the Netherlands. The Netherlands justified its failure to extradite them home as a concern that they would be subject to torture. However, it has not brought the persons in either case to trial before its national courts, and indeed the Convention Against Torture of 1984 does not compel the Netherlands to do $\mathrm{so}^{18}$. Another case in the Netherlands relates to a Rwandan refugee, Joseph Mumbara, accused of genocide in Rwanda. The Hague Criminal Tribunal rejected all the accusations against him and justified its judgment by saying that it lacked the competence to bring him to trial for genocide committed abroad, as the Dutch Penal Code does not permit prosecution under the UCJ. ${ }^{19}$

As noted, the aut dedere aut judicare is an agreed upon legal principle, which is applied by certain States who adopted the UCL in their national laws for prosecuting who committed a serious breach of international criminal law ${ }^{20}$. Further, the persons accused of inflicting torture walk freely in Amsterdam, despite common knowledge that they have committed torture in their countries. In this instance, we believe that the Dutch Supreme Court's claim regarding the absence of an international obligation to investigate crimes, or even the extradition of accused persons in accordance with the Conventions, seems to be a violation of recognized principles in international law ${ }^{21}$. Despite this, the Netherlands may also be classified as a unique country whose courts recognize UCJ, for example, it permits a lack of criminal conviction against the accused when giving a victim the right to financial compensation.

It is unacceptable to claim that it is impossible to apply any of the usual criminal jurisdictions, or even $\mathrm{UCJ}$, since persons accused of grave violations must not remain unprosecuted whatever the justification. The proof of the legitimate existence of UCJ in the Dutch legal system lies in the Dutch acknowledgement of allowing the courts to practise UCJ. Moreover, this acknowledgement confirms the Dutch concern we previously raised regarding the practice of $U C J$ in its courts.

\subsection{Swiss hesitation closer to rejection}

The Swiss Federal Justice has not taken a position on implementing UCJ for international crimes, although Switzerland initially found an easy way to practise UCJ in its national courts $^{22}$. The Swiss Penal Code did not provide for this jurisdiction and was not party to the Convention on the Prevention of the Crime of Genocide until 2000. However, this did

17 For more details about this case read: Amsterdam Appeal Court, Decision in 20 November 2000, R 97/163/12 et R 97/176/12.

18 Garrod, Matthew (2018). «Unraveling the Confused Relationship between Treaty Obligations to Extradite or Prosecute and universal Jurisdiction in the Light of the Habre Case», 59:1 Harvard International Law Journal 189.

19 See: District Court of the Hague, Case no. 09/750009-06 and 09/750007-07, Public Prosecutor v. Joseph Mpambara, Interlocutory Decision (24 July 2007. And also read: Hovell, Devika, « The Authority of Universal Jurisdiction», (2018) 29:2 European Journal of International Law 434.

20 Jalloh Charles, supra note at 5 p. 309.

21 La Fontaine, Fannie (2014). «L'Afrique face à la justice pénale internationale», $45: 1$ Etudes Internationales 135.

22 According to the article 35 of LOAP the Federal Criminal Court, have the competent at first instance and appeal for the crimes against the humanity, genocide and War crimes. Universal Jurisdiction Law and Practice in Switzerland, Trail International-Open Society, June 2019, p.27. 
not prevent the Lausanne military tribunal from trying a Rwandan refugee and convicting him of genocide in Rwanda during the armed conflict there in the $1990 \mathrm{~s}^{23}$. This judgment was seen as a progressive position by Swiss justice towards the adoption of UCJ. Indeed, in 2011, Switzerland issued a new law to amend its Federal Penal Code by transferring the prosecution of international crimes from military to civil criminal justice, and in so doing, it provided for the practice of UCJ by Swiss civil courts ${ }^{24}$. However, the 2011 law restricted this practice to certain conditions: 1) the establishment of a War Crimes Investigation Unit (WCIU) as a federal body in accordance with the amendment; 2) the accused being present in Switzerland at the time the complaint was filed; 3) the prosecution of war crimes committed in a country witnessing internal or international armed conflict ${ }^{25}$. In applying these restricted conditions, in 2011-2019, the WCIU has rejected more than sixty complaints regarding allegations of serious violations of international criminal and humanitarian law in various regions of the world. The WCIU based its rejections on the complaint's failure to fulfil one of the conditions of the 2011 law, especially the second and third noted above ${ }^{26}$. In this context, we refer to a case that lasted years and was continually refused by Switzerland, that of General Khaled Nizar, a former Algerian army commander in the 1990s. The Swiss authorities arrested the General in 2011 on charges of committing grave violations in Algeria against civilians. He was released after he pledged to appear before the court at a later date, but this did not happen ${ }^{27}$. His case was later raised between 2017 and 2018, but the Swiss Federal Public Prosecutor rejected the complaint submitted by NGOs, with the justification of lack of evidence of an internal or international armed conflict situation in Algeria between 1990 and 1999, and therefore that no war crimes had been committed ${ }^{28}$.

Another case has remained pending before the Swiss Justice for more than six years, that of a civilian warlord from Liberia called Ali Kousiah, who was accused of war crimes in his country during the internal armed conflict in the 1990s. After investigations by the WCIU, including the hearing and documenting of the testimony of twenty-five witnesses and many victims, the verdict was expected in April 2020, but due to COVID-19, it was postponed, and at the time of writing the accused is still detained ${ }^{29}$. The same situation has occurred with the former Gambian Minister of the Interior, Ousman Sonka, who is accused by NGOs and witnesses of the torture and rape of the wife of a political opponent, in addition to the killing of fifty-four Guinean refugees in Gambia. Since his asylum in Switzerland, his trial is ongoing and the Federal Court has approved his continued detention ${ }^{30}$.

The Swiss position on UCJ can thus be summarised briefly. Despite the enactment of a new law authorising Swiss civil courts to exercise UCJ instead of military tribunals, for the moment, it has not issued a single court ruling in accordance with this law. This is

23 Read the article 116 of Swiss military Criminal Code. www.parlement.ch. For more details about this case read: Garapan, Antonio (2002). «Des crimes qu'on ne peut ni punir ni pardonner», Paris: Odile Jacob, p.33. Bassiouni, Cherif (2001). «Universal Jurisdiction for International crimes: Historical perspective and Contemporary Practice», 42:1 Virginia Journal of International Law 145.

24 La Fontaine, Fannie, supra note 16 at 135.

25 For more details about the amended of the Swiss Penal law, see: Universal Jurisdiction Law and Practice in Switzerland, Trail International-Open Society, June 2019, p.14.

26 Garrod, Matthew, supra note 11 at 193.

27 Federal Criminal Court, Judgment of 25 July 2012, TPF BB.2011.140, para. 3.1.

28 Universal Jurisdiction Law and Practice in Switzerland, Trail International-Open Society, June 2019, p.17/37.

29 La Fontaine, Fannie, supra note 16 at 145 . Infra note 22 at 36.

30 For more information about his detention: www.swissinfo.ch/eng/ last visit 7 August 2020. 
truly regrettable, since countries neighbouring Switzerland have issued laws allowing the exercise of restricted UCJ and issued many verdicts according to their national laws ${ }^{31}$. In short, despite the frustration emerging over the past two decades among human rights defenders, following that of the victims, it seems that matters have made limited progress over the years. The first step is that the national courts of several European countries have issued sentences both of conviction and innocence against those accused of international crimes, and, most importantly, these sentences have been based on the principle of universal criminal jurisdiction. In other words, today the principle is being applied under new conditions that differ from those practised two decades ago.

\section{The UK: new criminal prosecutions based on universal jurisdiction}

Although the exercise of UCJ by British courts suffered a major setback after the House of Lords' verdict on the Pinochet case at the end of the 1990s, this did not silence NGOs, human rights defenders and legal advocates from demanding the abolition of the amnesty laws for those accused of international crimes, especially torture or war crimes. Thus, they sought the exercise of UCJ to confront criminals regardless of their political or military position at home, or the nationality of their victims ${ }^{32}$. Here, we note that a coalition of NGOs in Britain filed a complaint with the Central Criminal Court (CCC) in London against an Afghan refugee named Zardad Faryadi, who was accused by the British Justice of being an Afghan war lord ${ }^{33}$. He was tried before the CCC, which acquitted him of war crimes but found him guilty of torture in Afghanistan, when faced with some of his victims' and witnesses' testimony. He was sentenced to life imprisonment based on UCJ according to Article 134 of the Amended Criminal Justice Law of $1988^{34}$.

The verdict in the Zardad Faryadi case encouraged the NGOs and victims themselves to act against another suspect in Britain, a former Nepalese police colonel named Kumar Lama, who, while working in Nepal before his asylum in the UK, was accused of committing torture against civilians opposed to the Nepalese government. After filing a complaint against him in 2015 based on Article 134 of the Amended Criminal Justice Law, the Police Terrorist Crimes Investigation Unit (PTCIU) investigated the validity of the allegations against Mr. Lama and raised the investigations with the CCC, which was not convinced of their validity and acquitted him of the charges of torture ${ }^{35}$.

In a third case, concerning Reev Taylor, the Liberian ex-wife of former Liberian President Charles Taylor, she was accused in 2017 of torture in Liberia between 1990 and 2003. The CCC convicted and sentenced her to life imprisonment based on UCJ. Later, the Appeal Court accepted Taylor's appeal and cancelled out the judgement of the lower

31 For more about the rejected of Federal court of complaint filed by Mr. Nait-Liman since 1994. Read: The Case of Nait-Liman V. Swiss, Federal Criminal Court, n 51357/07 the Judgment on 15 March 2018, p. 11.

32 The application of Universal Jurisdiction, supra note 12 at 16.

33 Garrod, Matthew, supra note 5 at 170: Treacy J R. v. Zardad, Case No. T2203-7676 in 7 April 2004.

34 https://www.justiceinfo.net/fr/tribunaux/ last visit 13-6-2020; Hovell, Devika, supra note 12 at 428.

35 R v. Kumar Lama, Case no. 2013/05698 (Central Criminal Court, London, August 2016). It should be noted that the article 134/1 of Criminal Justice Act of 1988 stipulated (A public official or person acting in an official capacity, whatever his nationality, commits the offence of torture if in the United Kingdom or elsewhere he intentionally inflicts severe pain or suffering on another in the performance or purported performance of his official duties). Read: https://www.legislation.gov.uk/ukpga/1988/33/section/134. Last visit 6 August 2020. Shaghaji, Danial-Rezai, «Les crimes de Jus Cognes, le refus de l'immunité des hauts représentants des Etats étrangers et l'exercice de la compétence universelle », (2015) $28: 2$ Revue québécoise de droit international 152. 
court. The Appeal Court justified its decision on the basis that the case lacked sufficient evidence that the Liberian government, led by Charles Taylor, had actual control of the regions claiming she had committed torture. We may also add that she had no official position in her husband's government, and Article 1 of the Convention of Torture 1984 stipulates that the perpetrator of this crime must be in an official position. According to Article 135 of the Criminal Justice Act of 1988, the General Prosecutor should have given the green light to accuse an individual like Reev Taylor, and, since there was no agreement, the Appeal Court acquitted her in July 2020.36

Despite the disappointment that accompanied the Court's decision, we find that what is important is the significant change that occurred in the traditional position of the British judiciary, in rejecting the UCJ to rely on UCJ to indict, regardless of any conviction or acquittal. This new approach in the UK allows human rights organisations to submit more complaints, in particular of crimes of torture committed outside Britain, according to UC] and Article 134. Britain is one of the countries that require: 1) green light from the Public Prosecutor; and 2) the existence of an international legal obligation upon the UK. The latter occurred with the amended Criminal Justice Law 1988, which was issued to implement the 1984 Convention on the Prohibition of Torture.

\section{Sweden: a new experience in applying universal jurisdiction}

Sweden has conducted trials of persons accused of international crimes in accordance with UCJ based on the Global Crimes Law of 2013. This law covers the basic crimes stipulated in the Rome Statute, to which Sweden is party. The Swedish Penal Code was amended to include UCJ against perpetrators of international crimes and its application requires neither the presence of the accused or the victim on Swedish territory, nor for the act to be incriminated in the countries in which the victim or the accused are nationals. Unfortunately, there are countries, especially in the Middle East and Africa, which do not cover international crimes in their penal laws, to avoid accusing their own officials or leaders. In doing so, we see the necessity of the authorities agreeing to submit a complaint. Therefore, we face restricted UCJ by Swedish authorities ${ }^{37}$. Less than a year after the implementation of the Global Crimes Law, UCJ-based complaints were filed to Swedish courts on the genocide in Rwanda ${ }^{38}$. In June 2014, the Stockholm Criminal Court sentenced Rwandan Mbandida to life imprisonment for his role in the Rwandan genocide during the armed conflict there. Mr. Mbandida led a group of people to commit murder and kidnapping on an ethnic basis of the Tutsi tribe. Later, the Taboro case was filed and also involved a Rwandan citizen who was a refugee in Sweden. NGOs filed a complaint accusing him of the genocide, rape and murder of civilians in Rwanda in 1993, and demanded that he be tried based on UCJ. After a two-year trial before the Stockholm Criminal Court (SCC), he was found guilty in June 2018 and condemned to life in prison for genocide but acquitted of the other charges ${ }^{39}$. It is also possible to see a more

36 Judgment R v Reeves Taylor (Appellant) Supreme Court- EWCA/ Crim 2843, Judgment on 13 November 2019 , p. $6 / 49$.

37 Read the Report of Open Society (2020). «Universal Jurisdiction Law and Practice in Sweden», p.12 / last visit13 May 2020.

38 Ibid, p.11.

39 Bruggiamosca, Claire (2015). «Le génocide, une notion de droit international pénal dans le Code pénal Français: L'application au cas du procès de Pascal Simbikangwa» Revue International de Droit Pénal 12. 
progressive position being taken by the Swedish Justice in the February 2017 trial of a Syrian refugee who is a former member of the Free Syrian Army. NGOs filed allegations of war crimes in the Syrian conflict, and he was sentenced before the SCC to life imprisonment for killing seven Syrian army soldiers in May 2012, in northern Syria ${ }^{40}$.

\section{France: expanding the exercise of universal jurisdiction}

Over the past twenty-five years, France has witnessed numerous complaints against those accused of serious international crimes in the Former Yugoslavia and Rwanda, during the respective wars there, in addition to grave human rights violations committed in the Middle East and North Africa, as well as in sub-Saharan countries. Some of these complaints were closed by the Attorney General, while others were examined by various French criminal courts. The international crimes in question were war crimes, crimes against humanity, genocide, and torture, which are the most common forms ${ }^{41}$

\subsection{Specific and restricted laws with numerous applications}

Universal jurisdiction was regulated in France, starting with the laws ratifying certain conventions, and two laws issued respectively in 1995 and 1996 in relation to cooperation with the ICTY and ICTR, and the jurisdiction of the French judiciary to confront such violations in other circumstances ${ }^{42}$. In their application of the 1996 law, French courts issued mixed criminal rulings in three famous cases relating to the former Rwandan officials, Sampikanaawa, Barhari, and Naganzi, who were convicted of genocide during the armed conflict in Rwanda. With the exception of the rulings on the three cases above, the judicial trend that prevails in France unfortunately tends towards disrupting the enforcement of $\mathrm{UCJ}$, despite the media uproar accompanying any complaint submitted to the Prosecutor General of the French Republic ${ }^{43}$. It is true that France ratified a law in 1986, regarding the Convention on the Prohibition of Torture of 1984, in Article 5(2), giving it the mechanism for the exercise of UCJ. Unfortunately, France did not extend this to the ratification laws of other conventions no less important than the Torture Convention, such as the four Geneva Conventions of 1949 and their protocols of $1977^{44}$. Accordingly, the courts appear unable to prosecute persons accused of the grave violations stipulated in the said conventions ${ }^{45}$.

The intensity of the criticism of the French courts' position has not diminished the number of complaints lodged therewith. For many years, the application of UCJ in France has been associated with negative practices by the organs of executive authority, which have worked to hinder the enforcement of $\mathrm{UCJ}$ in several complaints against persons for whom arrest warrants were issued. Here, we note the complicity of the government with those

40 Han, Yuna (2017). «Rebirth of Universal Jurisdiction». May Ethics International affairs 1.

41 Hovell, Devika supra note 12 at 431. Garrod, Matthew, supra note 6 at 558 ; Aktypis, Spyridon, « L'adoption du droit pénal français au statut e la CPI : Etat des lieux», (2008) 7 Revue de droits fondamentaux 24.

42 The application of Universal Jurisdiction in the fight against impunity. Report published by European Union in 2016, p. 16-17.

43 Bassiouni, Cherif, supra note 14 at 139.

44 Gallie Martin et Dumont Helene (2005). «La Poursuite de Dirigeants en exercice devant une juridiction nationale pour des crimes internationaux: Le cas de la France», 18: 2 Revue québécoise de droit international 52.

45 Kalek, Wolfgang, supra note 11 at 936. 
accused of the crimes of torture and murder of civilians by asking them to leave French territories immediately. Such was the case with General Khaled Nizar, the former Algerian Minister of Defence, who has been accused in more than one European country of torturing civilians. Likewise, the case of Ould Day, who left France on French government advice and returned to his country, Mauritania, pledging to return the beginning of his trial, and failing to do $\mathrm{so}^{46}$. The French parliament has attempted, as a result of serious criticism against it, to address the apparent failure in its legislative approach by issuing laws cooperating with the ICTY in 1995, and with the ICTR in 1996, in harmony with the Convention against Torture. However, the accused must be present on French territory when a complaint is filed ${ }^{47}$. We believe that it is normal, especially for those accused of genocide and war crimes in Rwanda who have received humanitarian asylum in Belgium and France, to be seen by their victims or their relatives on the streets of Paris, Brussels, and other European cities.

After France became one of the first countries to ratify the Rome Statute twenty years ago, it took legislative measures to accommodate its national laws and the court statutes. At the forefront was the criminal immunity of the President of the Republic before the court, which the French Constitution modified to fit with Articles 25 and 27 of the ICC Statute ${ }^{48}$.

\subsection{New law to exercise the restricted universal jurisdiction}

The French parliament enacted a new law amending the Penal Code and procedures by adding new clauses to the two laws. The National Assembly has incidentally addressed $\mathrm{UCJ}$ and the conditions for its exercise in France. According to the amendment to the 2010 law, which includes adding paragraph 11 to Article 689 of the Penal Procedures Law, the Article was originally devoted to the conditions for the exercise by the French courts of its jurisdiction in accordance with the statute of the ICC. When these conditions do not apply, the French courts have two options: to extradite the accused to their country, or to try them before the French courts in accordance with $\mathrm{UCJ}^{49}$. The amended Article 689(11) specifies conditions for the exercise of UCJ by French courts, the foremost of which is that the accused resides in the French Republic at the time a complaint is submitted $^{50}$. This requirement is strictly enforced by the French courts, which require that the victim must establish the presence of the accused on French territory, based on

46 Ibid, 937.

47 Florence Bellivier (2014). «Compétence universelle: DE quoi nos gouvernants ont-ils peur?» 5 Observatoire justice et sécurité 5.

48 Bassiouni, Cherif, supra note 14 at 84.

49 The application of Universal Jurisdiction in the fight against impunity - Report published by European Union in 2016, p. 18.

50 Ascensio, Hervé (2010). «Une entrée mesurée dans la modernité du droit international pénal: À propos de la loi du 9 août 2010», 13 La Semaine Juridique 7.

See the case of Tunisian Officer Khalid bin Saeed who accused by the French justice committed torture crime against Tunisian woman when she visited Tunis in 1996. Later he worked in France as Consulate in Lyon, the ONGs complaint against him, unfortunately he return to his country. In 2008, the Strasbourg Court issued an judgment accused him to committed torture and convicted him prison 8 years in absentia, the court judgment based on article 689/2. Therefore, when the NGOs complaint filed he was in France and have legal residency in France, which mean that the practice of universal jurisdiction in this case based on the condition of residency actual for the perpetrator of the crime regardless of his diplomatic immunities according to Vienna convention of 1960. See Khaled Ben Saïd, Cour d'assises de Meurthe et Moselle (Nancy), 24 septembre 2010, 73/2010. See also the Disappeared of Brazzaville Beach Case in 2002, a criminal procedure was initiated against suspects founded in France. Kalek, wolfgang, supra note 11 at $936-937$. 
the aforementioned laws of the ICTY and ICTR. This condition has been heavily criticised in France and, with the issuance of the 2010 law, there has been discussion of the interpretation of what is meant by 'on French territory' and whether it means usual residence or in transit. By extrapolating the position of the French Prosecutor General in numerous complaints directed against foreign persons accused of crimes stipulated in the Rome Statute, it can be observed that arrest warrants have not been issued based on the fact that the accused was not actually residing in the Republic and was thus merely in transit or visiting.

On the other hand, the perpetrators of torture, genocide, and other grave violations of the Geneva Convention or crimes against humanity, according to the laws of 1995-1996, or even according to the law ratifying the Convention against Torture, the mere passage of the accused through French territories provides the right to issue an arrest warrant. The result is that the French are employing two different measures to fight one crime ${ }^{51}$. Certain accused persons have already been brought to trial before French courts and sentenced, sometimes to life imprisonment, while others have managed to escape justice. The general trend in France at that time was acceptance of the exercise of UCJ. France does not require the implementation of $U C$ J to be based on the existence of an international crime, but rather on a national law not reliant on an international obligation. The exercise of UCJ by French courts has therefore required several legal changes in the French legal system, in particular the amendment of the Code of Criminal Procedure and the Penal Code, in order to consider the rapid developments associated with the adhoc tribunals for the Former Yugoslavia and Rwanda, and accession to the ICC. This is in addition to expanding the scope of the application of UCJ in French courts ${ }^{52}$. Article 689 (11) stipulates a new condition, which is that for the accused to be prosecuted in France, they must not have been fully tried for the act outside France. This condition is classified as a procedural and not objective condition. The aim of applying $U C J$ is for the accused to be tried and punished. It is natural that they will not be punished twice for the same act to confront the amnesty laws that many countries have enacted regarding international crimes, especially those of military and political leaders ${ }^{53}$.

The last condition for applying UCJ relates to the decision of the Public Prosecutor to initiate criminal procedures only in relation to crimes stipulated in the Rome Statute. It excludes crimes covered by the principle of UCJ in accordance with the laws of 19951996 or the conventions to which France is a party, according to the ratification law ${ }^{54}$.

\subsection{The Conflict in Syria: A precious opportunity for an important practice}

The EU has imposed sanctions on political and military officials in the Syrian regime, and international committees have been formed to verify grave violations of humanitarian

51 Mathe, Francoise (2014). «la défense devant les juridictions françaises saisies au titre de la compétence universelle», $4: 4$ Les cahiers de la droit 594 ss.

52 The application of Universal Jurisdiction supra note 12 at 18 . For more details about the French Courts trends see: Universal Jurisdiction Law and Practice in France, Trail International-Open Society, February 2019, p. 4.

53 Ibid p.19.

54 Scharf, Michael (2012). «Universal Jurisdiction and the Crime of Aggression», 53:2 Harvard Journal of International Law 364. Read Mathe, Francoise, supra note 44 at 595. 
law in Syria. The Caesar Law, issued by the US House of Representatives, is based on the consensus of European and American NGOs for human rights. It describes acts committed in Syria since 2011 as war crimes and crimes against humanity committed by the Assad regime, opposition groups, and ISIS.

These factors have encouraged French NGOs to file complaints primarily accusing political, security and military officials of the regime of torture and war crimes against Syrian civilians, while members of the opposition groups were accused of crimes against the Syrian army and its associated militias ${ }^{55}$. Since 2016, human rights organisations have lodged numerous complaints against figures in the Syrian regime. After serious investigations ordered by the French Attorney General, international arrest warrants were issued in November 2018 by the investigating judge in Paris against three important figures in Syrian security institutions. These are the first warrants in France regarding grave violations in Syria. The first warrant concerned Ali Mamlouk, Director of Syrian Intelligence and Head of the Syrian National Security Council, which incorporates all of Syria's security services. Mamlouk was accused of torture and enforced disappearance crimes against European citizens, such as the Germans Mazen and Patrick Dabbagh in November $2013^{56}$. The second was an international arrest warrant issued against Jamil Hassan, Director of Syrian Airforce Intelligence, who was accused of crimes against humanity, foremost of which is torture against Syrian civilians, based on a complaint filed by Syrian refugees residing in the French Rhine. The third warrant accused General Abd al-Salam Mahmoud, Director of Air Force Intelligence in Bab Touma, near Damascus, of the torture of Syrian civilians during peaceful demonstrations there. Despite the importance of the three warrants, it is disappointing that the accused are in Syria, and therefore it will be almost impossible for them to be in France. Their presence in a European Union country is more likely since Ali Mamlouk went to in Rome and met with Italian security officials, but then left for Syria. Here, criticism has been directed at Italy for allowing him to depart despite the French arrest warrant, which all EU countries are committed to respect ${ }^{57}$.

Nevertheless, the question remains as to whether the French courts' issuance of judicial rulings can be based on in absentia UCJ, and this has not been applied as yet. Indeed, the French courts have stressed the condition of actual residence in France by the accused in order to implement UCJ. Accordingly, we believe that it is not enough to issue arrest warrants based on victims' and their families'. testimony and complaints. Rather, what is required is to proceed with the procedures for a trial in absentia and thus enforce the 2010 law establishing UCJ, especially given that Syria is not a member of the ICC and is not expected to be in the foreseeable future.

\section{Universal jurisdiction: ongoing German practice}

Contrary to the neutral, if not passive, approach of German foreign policy towards international issues, it is notable that the German legislator and judiciary have a very

55 Universal Jurisdiction Law and Practice in France, Trail International-Open Society, February 2019, p. 9.

56 Vincent, Elise (2016). Une plainte contre Damas déposée à Paris pour « crimes contre l'humanité, le monde, le 24 octobre. www.lemonde.fr, last visit 10 August 2020. Infra note 50 at 22.

57 Vincent, Elise (2018). Trois dignitaires syriens visés par des mandats d'arrêt émis par la justice française, le monde, le 5 novembre. www.lemonde.fr, last visit 12 August 2020. 
positive and progressive approach towards the legislative adoption and exercise of UCJ. This trend is related to the German judiciary's issuance of judicial rulings based on UC] and followed by the enactment of a law which transfers crimes stipulated in the Rome Statute to the internal legal system. This transfer justifies the exercise by the German judiciary of $U C J$ towards the perpetrators of such crimes. The armed conflicts in the Middle East and the associated waves of asylum seekers to Germany have alerted the German authorities to the fact that many among these asylum seekers are accused of torture, war crimes, and crimes against humanity. This has increased the effectiveness of the judicial adoption of universal jurisdiction ${ }^{58}$.

\subsection{Perpetrators of international crimes appearing before the German courts}

The German recognition of UCJ dates back to the 1990s, when German courts made charges of genocide and crimes against humanity against people fleeing conflict in the Former Yugoslavia and Rwanda. At the time, the number of judgments was just four. The German courts applied UCJ according to Article 6(1-8) of the German Penal Code, which stipulates the existence of an international convention, to which Germany is a party, and includes criminalisation of the aforementioned acts. However, the German judiciary added a new condition related to the existence of a link between the crime and Germany. Subsequently, the Federal Supreme Court overturned this requirement in the Sokolovic case, stating that the international obligation in the convention is sufficient to oblige German courts to prosecute the perpetrators of international crimes ${ }^{59}$.

The first widely accepted convention of UCJ during this period was the Convention for the Genocide of 1948, even though no judgments were made related to crimes against humanity or war crimes. Among the most prominent cases, the German court in Dusseldorf in 1997 considered the Nikola Jorgic case, a Bosnian Serb residing in Dusseldorf with his family, and charged with genocide against Muslim civilians in Bosnia and Herzegovina during the armed conflict there. The German court established its UC] in accordance with Article 220a of the German Penal Code on the Criminalisation of Genocide, which quoted the text of Article 2 of the Genocide Convention of 1948. In addition to Article 6(1) of the German Penal Code, the Court decided that there were several links between the crimes committed and Germany, most notably: German humanitarian and military intervention in Bosnia, and the fact that the accused and his family were residing in Germany. He was convicted to life imprisonment and died in 2014 in prison ${ }^{60}$.

The second case is that of Đajić, a Bosnian Serb soldier accused of murdering twentytwo Bosnian Muslims in June 1992. After escaping to Germany and seeking asylum, NGOs filed a complaint on behalf of the victims and he was tried before the Bavarian Criminal Court, which sentenced him to five years in prison for murdering Bosnian civilians. However, the court failed to establish the special intention (dol special) required for the

58 The application of Universal Jurisdiction supra notes 12 at 18.

59 Bassiouni, Cherif, supra note 14 at 143.

60 Ryngaert, Cedric (2008). «Universal Criminal Jurisdiction », (2008) Criminal Law Forum 354. Read more: Gurda Veded (2015). «The Prosecution of Genocide in Bosnia before International Domestic and National Courts of other Jurisdictions», July Research Gate 39. 
crime of genocide, which is the intention to destroy, in whole or in part, a protected group (i.e. on ethnic, religious, national, race, or linguistic grounds). The Đajić conviction was based on UCJ, on Article 2 of the Fourth Geneva Convention of 1949, which protects civilians during an international armed conflict, and is a description of the conflict between the respective Republics of Bosnia and Herzegovina and Serbia ${ }^{61}$.

The same Bavarian Criminal Court was also able to convict another Serbian leader, Kušljić, for committing crimes of ethnic cleansing against Muslims in Bosnia, based on UCJ as stipulated in Article 6 of the German Penal Code. Germany is internationally committed to the Genocide Convention, and Kušljić was convicted and sentenced to life imprisonment. Importantly, the Federal Supreme Court rejected his appeal disputing the UCJ of the court ${ }^{62}$. Finally, there was the case of Sokolovic, a Bosnian Serb convicted by the Dusseldorf Court and sentenced to nine years in prison for genocide against Bosnian Muslims in 1992. The importance of this case is reflected in the decision of the German Federal Court, which modified the trend of the German judiciary to refuse the need for a link between the perpetrator of the crime and Germany ${ }^{63}$. This decision subsequently had a positive impact on the course of the complaints lodged with the German courts, although not all of them were applied, such as with the complaint filed against the former US Secretary of Defence, Donald Rumsfeld, and another against the former Minister of the Interior of Uzbekistan, Mr. Almatov ${ }^{64}$.

\subsection{Universal jurisdiction in the law on crimes against international law}

As part of its commitment to the Rome Statute established by the ICC, the German Federal Parliament enacted the so-called Crimes against International Law Act in 2002. Under this law, crimes stipulated in the Rome Statute were combined with numerous amendments in the distribution of types of crimes: genocide, crimes against humanity, war crimes, aggression, and grave violations stipulated in the four Geneva Conventions and its two optional protocols of 1977. Article 1 of the Crimes against International Law Act stipulates the jurisdiction of the German judiciary to prosecute these crimes, which it described as being committed outside Germany and having no connection to it ${ }^{65}$. Germany's application of this law coincided with conflict in the Middle East region, in Afghanistan and Iraq and, in 2006, German human rights organisations filed complaints on behalf of civilian victims against American political and military officials, including one complaint in the name of eleven detainee torture victims at Abu Ghraib prison in Iraq. They accused former US Secretary of Defence Donald Rumsfeld of committing crimes of torture. The complaint was based on the UCJ principle stipulated in the 2002 law, in that torture of civilian detainees during the US occupation of Iraq is classified as a crime against international law ${ }^{66}$. However, in April 2007, the Federal Prosecutor dismissed the

61 Stegmiller, Ignaz (2008). «German Research on International Criminal Law», 19 Criminal Law Forum 186.

62 Shaghaji, Danial (2015). «L'exercice de la compétence universelle en tant qu'obligation Erga Omnes a fin de réprimer les crimes de Jus Cognes», Research Gate 3.

63 Gurda Veded, supra note 53 at 38.

64 Masse, Michel, supra note 11 at 446.

65 Gurda Veded, supra note 53 at 39.

66 Ambos, Kai (2007). «International Core Crimes, Universal Jurisdiction and $\S 153 F$ of the German Procedure Code: A Commentary on the Decision of the Federal Prosecutor General and the Stuttgart Higher Regional 
complaint against Rumsfeld, stating that there was no link between Germany and the crime committed, and that the accused had not entered German soil at the time the complaint was filed. Here, we note that the Federal Supreme Court, in its judicial ruling in the Sokolovic case, abolished the association condition, and, therefore, we believe that basis for the judicial ruling was incorrect. We also point out that the German courts have examined many complaints related to the application of UCJ and issued in absentia rulings against accused perpetrators ${ }^{67}$. The same refusal was repeated in another case submitted in 2005 against another foreign political official, the former Uzbek Interior Minister Almatov, who was accused by Uzbek refugees in Germany of committing crimes against humanity (torture) on civilians in Uzbekistan. Unfortunately, the German Prosecutor rejected the complaints for two reasons: the acts of torture in question were committed before the entry into force of the 2002 law in Germany; and there was no connection between the crime and Germany.

We believe that the German judiciary's position on these two complaints was based on unspoken political reasons (i.e. pressure from major countries such as the United States, and developing relations with Uzbekistan), as well as the declared legal reasons. In another case, the Frankfurt Court issued a guilty verdict against a Rwandan residing in Germany called Unsevor [sic], a former Rwandan mayor accused of exterminating more than 3,700 civilians of the Tutsi minority in 1993. He was convicted in 2015 and sentenced to life imprisonment. The Frankfurt Court applied Article 220a of the German Penal Code regarding genocide, as the act committed occurred before the 2002 law was passed $^{68}$.

\subsection{Germany's new refugees: a countless list of accused persons}

The conflict in the Middle East in the past decade has caused millions of refugees to flow to Europe, commonly Germany. Among the refugees, classified as one of the most vulnerable groups in the world, we find victims of war crimes and crimes against humanity committed in their countries by the political regimes that govern them, or by other armed and/or terrorist groups such as Al Qaeda, ISIS, or Hezbollah ${ }^{69}$. Within the wider group of refugees, there are officials and military personnel from these latter groups who have committed war crimes, crimes against humanity, and even extermination. The reason for their escape to Germany is because they fear for their lives or hope for a new life without thinking about the crimes they have committed. In response to these new developments, the German government established an Investigation Unit concerned with war crimes committed in Syria, Iraq, and Libya. Starting in 2011, this unit obtained information on 2,800 war crimes and crimes against humanity, and testimonies from more than 200 witnesses to these violations ${ }^{70}$. NGOs in Germany and Syria have helped to document the information and testimonies of victims and their relatives. Over ten complaints have been submitted to the Federal Public

Court in the Abu Gharib/Rumsfeld Case», 58 Criminal Law Forum 44. Also read: The Legal Framework for Universal Jurisdcition in Germany. Report published by HRW in 2014, p. 5-7.

67 La Fontaine, Fannie, supra note 16 at 136.

68 Hovell, Devika, supra note 15 at 448.

69 Kroker, Patrick (2018). «Syrian Torture Investigations in Germany and Beyond», 16 Journal of International Criminal Justice 167.

70 Han, Yuna, supra note 30 at 1. 
Prosecutor in Germany, focusing on charges of torture, crimes against humanity, and war crimes in Syria, mainly by members of the Syrian regime and, to a lesser extent, by the Syrian opposition and ISIS. These complaints relate to two defendants already on German soil who have or will obtain refugee status. Other complaints have been lodged against regime officials in Syria under the principle of UCJ in absentia. T welve such complaints have been filed ${ }^{71}$.

At the forefront of the cases being considered by the German criminal judicial system is that of the refugee Muhammad Khalaf, who obtained refugee status in 2015. Human rights organisations have accused him of participating in the commission of war crimes in Syria between 2012 and 2013 through his membership of the Free Syrian Army, against militia members loyal to the Syrian regime in Idleb. He was arrested in June 2018, and the case was referred to the Stuttgart Criminal Court. The court based its accusations against him on Article 8(1-3) of the Crimes against International Law of 2002, which is based on Article 1 of the same law that allows the German judiciary to exercise UCJ if a war crime, crime against humanity, or genocide has been committed outside of Germany by non-Germans. The presence of the accused in Germany and his legal residence within it prevented the defence from establishing a link between the crime and Germany. In addition, the presence of the WCIU in Syria, Iraq, and Libya established an association between Germany and these three countries ${ }^{72}$. The Stuttgart Court found him guilty and sentenced him to four and a half years in prison in April 2019. The court explained that the sentence was reduced because he had integrated into German society and been subjected to great psychological pressure because of the war in Syria. Further, he had no legal or criminal violations in Germany since his arrival in 2015. Recently, in 25 February 2021, the Higher Regional Court of Koblenz sentenced Iyad Al-Ghareib to four and a half years in prison. He was a former Syrian secret police officer who was arrested by German police on the basis of an arrest warrant. The Koblenz Court found him guilty of committing acts of torture as crime against humanity against more than four thousand people and killing fifty-eight of the detainees at their military unit in Syria ${ }^{73}$.

As for complaints still being considered by the German Federal Prosecutor, these are related to certain Syrian officials charged with the torture of Syrian-German citizens, or Syrians who had sought refuge in Germany. Here, we refer to the 2009 arrest warrant issued by the German Public Prosecutor against Jamil Al-Hassan, Director of Air Force Intelligence (the worst Syrian Intelligence Office in terms of committing violations, even before the outbreak of unrest in Syria 2011). Since 2011, Jamil Al-Hassan has been sanctioned by the US and Europe for grave violations against Syrian civilians. In March 2017, European human rights organisations lodged complaints with the German Public Prosecutor on behalf of seven Syrian victims who accused Jamil Al-Hassan of torture between 2011 and 2015. Of these seven, three German victims of Syrian origin are Mazen Dabbagh, his son Patrick, and Abdel Moneim Hamdo. In a significant development, the German Prosecutor issued an international arrest warrant against Jamil Al-Hassan, based on the UCJ and in accordance with the Crimes against International Law of 2002, in

Hovell, Devika, supra note 15 at 448.

Kroker, Patrick, supra note 64 at 168.

www.lemonde.fr, last visit 25 march 2021. 
particular Article $7(1-5)$ and Article $1^{74}$. Until this point, the German judiciary had not referred to an in absentia trial, and it is not known what caused this delay, since the German WCIU, and Public Prosecution investigations had been completed. However, as long as Jamil Hassan and others remain in power in their country, criminal justice is postponed. It is certain that Syria will not extradite him to Germany or France, the two countries which have issued international arrest warrants against him and others, and so the relatives of his victims can only but wait.

\section{Conclusion}

There are 113 countries recognising UCJ in their national laws throughout the world, but those which have actually applied this jurisdiction are few. UCJ is not applied in Asia and has been rejected in Africa by the African Union because, according to the Union, it only targets African leaders ${ }^{75}$. In Central and South America, to date it is not known if it has been applied anywhere on these continents, despite limited attempts in countries such as Argentina and Mexico. Moreover, in the USA it has been applied in a similarly limited and also selective manner, and has thus not been established as a legal principle there. As for Europe, we note that western European countries were the first to apply this jurisdiction more than twenty-five years ago. However, this application was more akin to what may be called complementary jurisdiction, in that all the defendants convicted before European courts under UCJ during the 1990s and the beginning of this century were from specific countries: Rwanda, the Former Yugoslavia, and the Democratic Republic of the Congo. In addition to the international criminalisation of the acts of a perpetrator, we may say that there has also been some demonisation of the accused in these countries. Two primary factors have provided political cover for governments and subsequently European courts to issue criminal judgements, some severe and others moderate, against the perpetrators of war crimes, crimes against humanity, and genocide, as we have shown. Subsequent demands for the application of UCJ in western European countries themselves were, however, aimed at the senior political and military officials of major countries, thus colliding with unspoken governmental veto, and resulting in limited arrest warrants that are then cancelled, and the failure to bring any of these officials to trial, even in absentia. Being dissatisfied with the previous procedures, governments instead amended national laws related to the application of $\mathrm{UCJ}$ in such a way as to make it more restrictive, if not toothless in some countries. It is true that certain legal justifications for stopping the application of absolute UCJ remain valid and cannot be overlooked. For example, regarding State sovereignty, the immunity of heads of state and high-ranking officials is an obstacle that the International Court of Justice has yet to overcome in its trade-off between UCJ and the immunity of an African country's foreign minister. Moreover, punishment exemption laws are also legislated to protect senior officials and leaders accused of international crimes. However, these justifications were not considered in either Belgium's position on the arrest warrant for a former Foreign Minister of the Democratic Republic of the Congo, and the matter reached the International Court of Justice, or the first phase of the Hissène Habré case. Today, certain countries continue to go beyond these legal justifications and issue arrest

74 Weider, Thomas (2019). Le monde, crimes contre I'humanité: trois Syriens arrêtés en France et en Allemagne, le 14 février 2019. www.lemonde.fr, dernière visite 20 aout 2020.

75 Garrod, Matthew, supra note 6 at 559. 
warrants for senior officials still in power in their countries. The obvious example is Syria. It is true that punishing a criminal is better than allowing him to go unpunished, and so the serious violations in Syria cannot be tolerated, regardless of the identity or political or military rank of the perpetrator. On the other hand, some European countries have amended their national laws to repeal the principle of UCJ in absentia, and so the question that arises is how the return can be legally explained when one such accused is handed over. We believe that re-exercising what we have called the complementary jurisdiction is what justifies the issuance of international warrants against members of the Syrian regime, particularly since these officials are themselves subject to sanctions from the EU and US. They are also the subject of a clear accusation of the commission of war crimes by the United Nations investigation committees formed for this purpose. However, we would argue that trials in European countries of Syrian defendants and other refugees are a positive and important step to achieving justice for the victims of grave violations in Syria and elsewhere.

\section{References}

\section{Books}

Cassese, A (2002). Crimes internationaux et juridictions internationales. Paris: PUF. Garapan, A (2002). Des crimes qu'on ne peut ni punir ni pardonner. Paris: Odile Jacob Pradelle, G (2000). «La compétence universelle». Ascensio, Hervé (dir) Droit international pénal. Paris: Editions A-Pédone .

Vandermeersch, D (2003). «La fiabilité de la règle de la compétence universelle». Fronza, Emanuela et Manacorda, Stefano (dir). La justice pénale internationale dans les décisions des tribunaux ad hoc-Etudes Law Clinics en droit pénal international. Milano: Giuffré Editoire.

\section{Articles}

Aktypis. S (2008). «L'adoption du droit pénal français au statut e la CPI: Etat des lieux», Revue de droits fondamentaux, 7. 1-35.

Ambos. K (2007). «International Core Crimes, Universal Jurisdiction and $\S 153 \mathrm{~F}$ of the German Procedure Code: A Commentary on the Decision of the Federal Prosecutor General and the Stuttgart Higher Regional Court in the Abu Gharib/Rumsfeld Case», Criminal Law Forum 18.43-58.

Ascensio. H (2010). «Une entrée mesurée dans la modernité du droit international pénal: À propos de la loi du 9 août 2010», La Semaine Juridique 13. 1691-1698.

Bassiouni. C (2001). «Universal Jurisdiction for International Crimes: Historical perspective and Contemporary Practice», Virginia Journal of International Law 42:1.283.

Bruggiamosca. C (2015). «Le génocide, une notion de droit international pénal dans le Code pénal Français: L'application au cas du procès de Pascal Simbikangwa», Revue International de Droit Pénal. 1-12. 
Florence. B (2014). «Compétence universelle: De quoi nos gouvernants ont-ils peur?» Observatoire justice et sécurité 5.1-14.

Fontaine. F (2014). «L'Afrique face à la justice pénale internationale», Etudes Internationales 45: 1.129-151.

Gallie. M ( 2005). «La Poursuite de Dirigeants en exercice devant une juridiction nationale pour des crimes internationaux: Le cas de la France», Revue québécoise de droit international 18: 2.

Garrod. M (2018). «Unraveling the Confused Relationship between Treaty Obligations to Extradite or Prosecute and Universal Jurisdiction in the Light of the Habre Case», Harvard International Law Journal 59: 1.125-196.

Garrod. M (2019). «The Emergence of Universal jurisdiction in Response to Somali Piracy: An Empirically Informed Critique of International Law's Paradigmatic Universal Jurisdiction». Chines Journal of International Law, 18. 551-643.

Gurda. V (2015). «The Prosecution of Genocide in Bosnia before International Domestic and National Courts of other Jurisdictions», Research Gate 39. 35-69.

Han. Y (2017). «Rebirth of Universal Jurisdiction», Ethics International affairs 1. 1-4.

Heller. K. (2017). «What Is an International Crime? A Revisionist History», Harvard International Law Journal 58: 2.353-420.

Hovell. D (2018). «The Authority of Universal Jurisdiction», European Journal of International Law, 29: 2.427-456.

Kalek.W (2009). «From Pinochet to Rumsfeld: Universal Jurisdiction in Europe 19982008», Michigan Journal of International Law, 30: 3.927-980.

Klip. A (2008). «Universal Juridiction: Report for Europe», Revue International de Droit Pénal, 79. 173-196.

Kontorovich. E (2008). «The Inefficiency of Universal Jurisdiction», University of Illinois Law Review 1. 4-27.

Kroker. P (2018). «Syrian Torture Investigations in Germany and Beyond», Journal of International Criminal Justice, 16. 165-191.

Langer.M (2015). «Universal Jurisdiction is Not Disappearing», Journal of International Criminal Justice 13: 2.246-256.

Massé. M (2008). «Chronique de droit pénal international», Revue de Science Criminelle et de Droit Pénal Comparé, 3. 447-459.

Mathe. F (2014). «La défense devant les juridictions françaises saisies au titre de la compétence universelle», Les cahiers de la droit, 4 :4.593-605.

Ryngaert. C (2008). «Universal Criminal Jurisdiction», Criminal Law Forum, 19.353-357.

Shaghaji. R (2015). «L'exercice de la compétence universelle en tant qu'obligation Erga Omnes afin de réprimer les crimes de Jus Cognes», Revue International de Droit Comparé. 1-17. 
Shaghaji. R (2015). «Les crimes de Jus Cognes, le refus de l'immunité des hauts représentants des Etats étrangers et l'exercice de la compétence universelle», Revue québécoise de droit international 28: 2.143-171.

Scharf, M (2021). «Universal Jurisdiction and the Crime of Aggression», Harvard Journal of International Law 53:2. 357-389.

Stegmiller, I (2008). «German Research on International Criminal Law», Criminal Law Forum 19.415-437.

\section{Reports of NGOs}

The Application of Universal Jurisdiction in the Fight against Impunity - Report published by European Union in 2016, p.1-23.

Universal Jurisdiction Law and Practice in Switzerland, Trail International - Open Society, June 2019, p.1-41.

Universal Jurisdiction Law and Practice in Sweden, Report of Open Society, May 2020, p.1-27.

Universal Jurisdiction Law and Practice in France, Trail International-Open Society, February 2019, pp.1-43.

The Legal Framework for Universal Jurisdiction in Germany. Report published by HRW in 2014, p. 1-10.

\section{Reports/ Resolutions of of UN}

GAUN-6th Commission, 73 Session, GA/3571, 10-10-2018.

GAUN, Res.64/117 in January/15/20210.

Jalloh Charles, Universal Criminal Jurisdiction, International Law Commission / Doc. A/73/10, 2018. 307-325.

\section{Judgments of Dutch Courts}

Amsterdam Appeal Court, Decision in 20 November 2000, R 97/163/12 and R 97/176/12.

District Court of The Hague, Case no. 09/750009-06 and 09/750007-07, Public Prosecutor v. Joseph Mpambara, Interlocutory Decision in 24 July 2007.

\section{Judgments of Switzerland Courts}

Federal Criminal Court, Judgment of 25 July 2012, TPF BB.2011.140.

The Case of Nait-Liman V. Swiss, Federal Criminal Court, N.51357/07 the Judgment on 15 March 2018.

\section{Judgments of British Courts}

Treacy J R. v. Zardad, Supreme Court- Case No. T2203-7676 in 7 April 2004.

R v. Kumar Lama, Case no. 2013/05698 (Central Criminal Court, London, August 2016). Judgment R v Reeves Taylor (Appellant) Supreme Court- EWCA/ Crim 2843, Judgment on 13 November 2019. 


\section{Judgments of German Courts}

Urtil des Bundesgerichtshof (Maksim Sokolovic) (3 StR 372/00) vom 21 Februar 2001 (The Judgment of Federal Court of Justice).

Urteil des Obrelandesgericht Düsseldorf (Nikola Jorgic) (IV-26-96) vom 26. September 1997. (The judgement of Suprema Regional Court of Nort Rhine-Westphalia, Dusseldorf.

Urteil des Bundesgerichtshof (Djurad Kuslic) (3 StR 244/00) vom 21. Februar 2001. (The Judgement of Federal Court of Justice).

\section{Judgments of French Courts}

Khaled Ben Saïd, Cour d'assises de Meurthe et Moselle, 24 September 2010, N 73/2010.

\section{European newspapers}

Madjid Zerrouky, La condamnation d'un tortionnaire syrien en Allemagne, une première «historique», le 25 février 2021. www.lemonde.fr, Last visit 25 March 2021.

Vincent, Elise, Une plainte contre Damas déposée à Paris pour «crimes contre I'humanité, le monde, le 24 octobre 2016. www.lemonde.fr, last visit 10 August 2020.

Vincent, Elise, Trois dignitaires syriens visés par des mandats d'arrêt émis par la justice française, le monde, le 5 novembre 2018. www.lemonde.fr, last visit 12 August 2020.

Weider, Thomas, Le monde, crimes contre I'humanité : trois Syriens arrêtés en France et en Allemagne, le 14 février 2019. www.lemonde.fr, last visit 20 August 2020. 